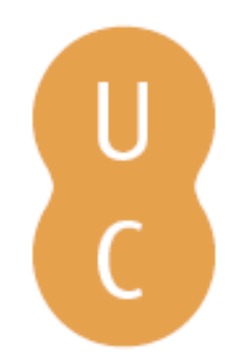

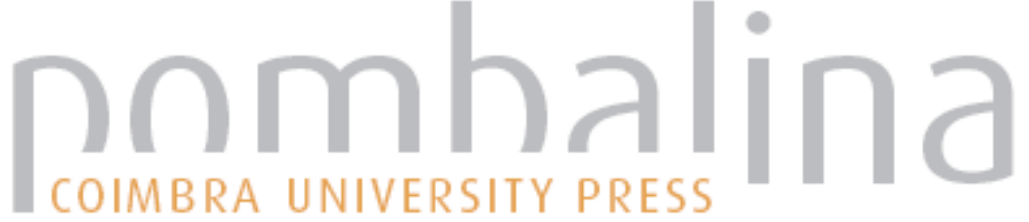

\section{Problemas dermatológicos mais comuns em pediatria}

Autor(es): Januário, Gustavo

Publicado por: Imprensa da Universidade de Coimbra

URL

persistente: URI:http://hdl.handle.net/10316.2/43130

DOI: $\quad$ DOI:https://doi.org/10.14195/978-989-26-1300-0_29

Accessed : $\quad$ 26-Apr-2023 11:59:02

A navegação consulta e descarregamento dos títulos inseridos nas Bibliotecas Digitais UC Digitalis, UC Pombalina e UC Impactum, pressupõem a aceitação plena e sem reservas dos Termos e Condições de Uso destas Bibliotecas Digitais, disponíveis em https://digitalis.uc.pt/pt-pt/termos.

Conforme exposto nos referidos Termos e Condições de Uso, o descarregamento de títulos de acesso restrito requer uma licença válida de autorização devendo o utilizador aceder ao(s) documento(s) a partir de um endereço de IP da instituição detentora da supramencionada licença.

Ao utilizador é apenas permitido o descarregamento para uso pessoal, pelo que o emprego do(s) título(s) descarregado(s) para outro fim, designadamente comercial, carece de autorização do respetivo autor ou editor da obra.

Na medida em que todas as obras da UC Digitalis se encontram protegidas pelo Código do Direito de Autor e Direitos Conexos e demais legislação aplicável, toda a cópia, parcial ou total, deste documento, nos casos em que é legalmente admitida, deverá conter ou fazer-se acompanhar por este aviso.

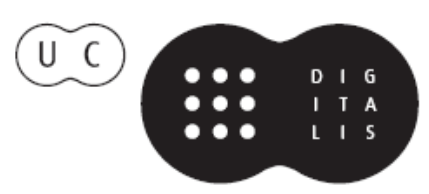




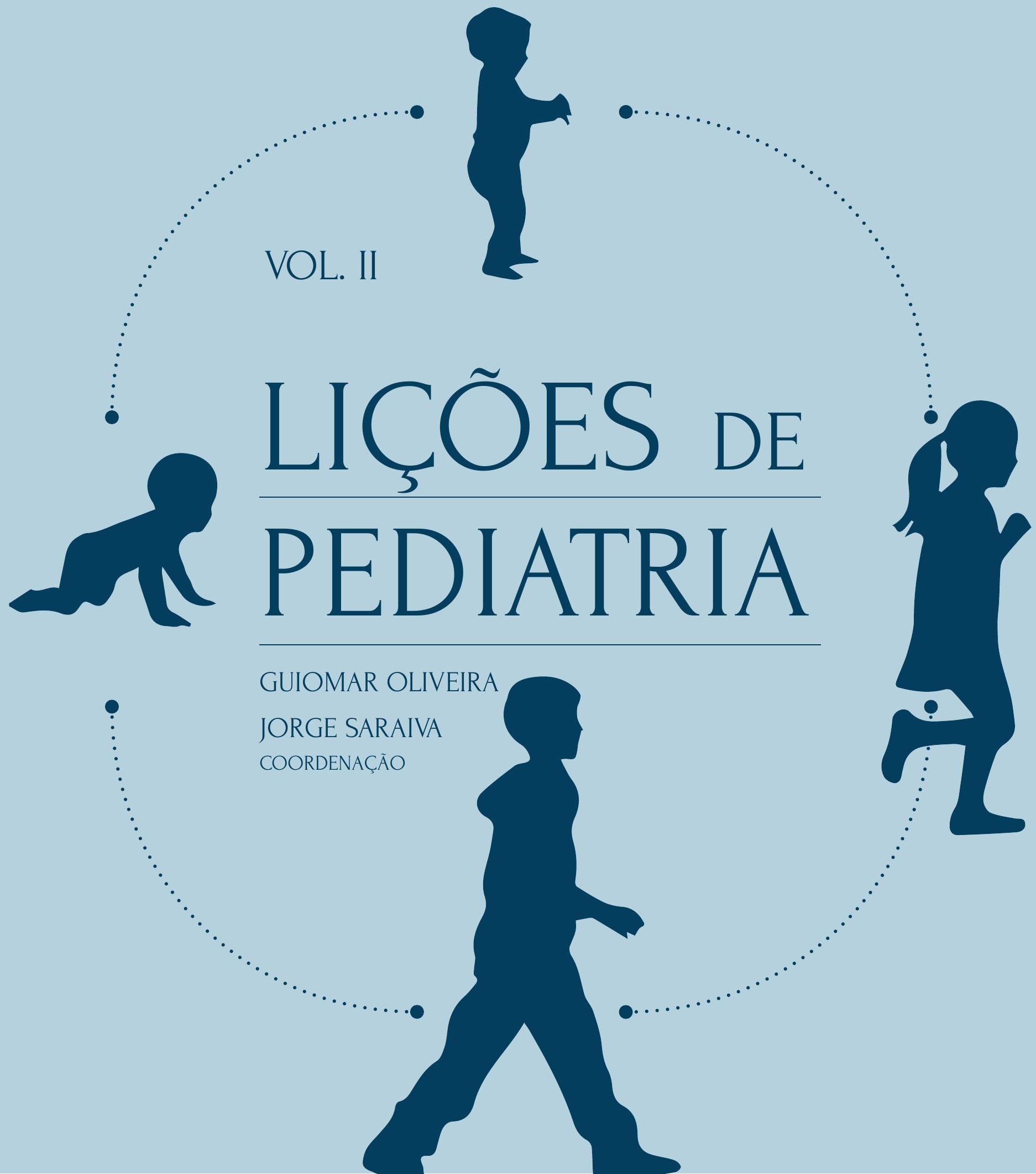


Capítulo 29.

Problemas dermatológicos mais comuns em pediatria
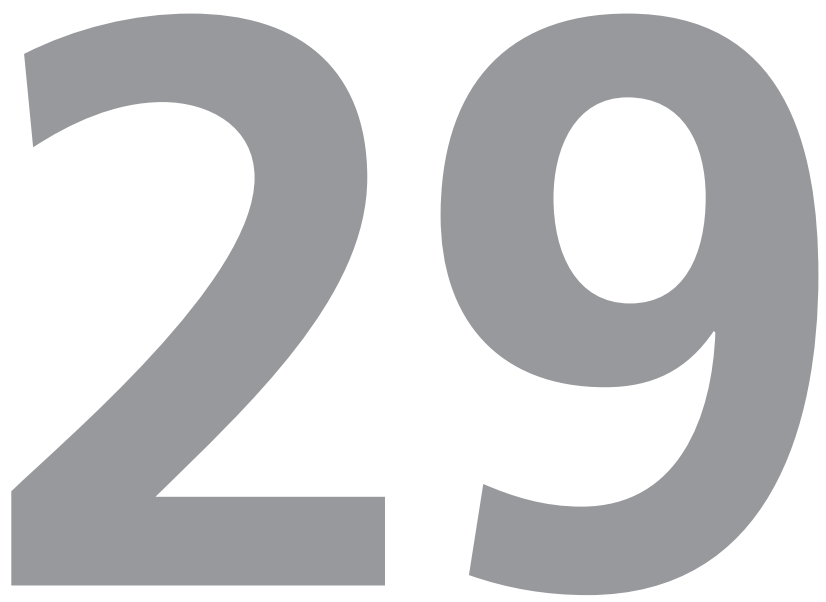

\section{Gustavo Januário}




\subsection{CONTEXTO}

Os problemas dermatológicos são muito frequentes em Pediatria.

No desenvolvimento deste tema vamos dividir a sua abordagem em duas áreas: a pele do recém-nascido (RN) e do pequeno lactente e as suas alterações fisiológicas; e de seguida os problemas da pele nas crianças em geral.

\subsection{DESCRIÇÃO DO TEMA}

\subsubsection{Alterações cutâneas fisiológicas do recém-nascido e do lactente}

As alterações cutâneas fisiológicas do recém-nascido (RN) são caracterizadas por serem habitualmente exclusivas do período neonatal e pelo seu carácter benigno e transitório, refletindo sobretudo a imaturidade dos vários compartimentos cutâneos, sendo o reflexo da transição da vida intrauterina para o meio exterior. Apesar da sua benignidade, estas são muitas vezes interpretadas como anormais e portanto geradoras de dúvidas para os pais e para os médicos. Não necessitam de tratamento mas o seu diagnóstico diferencial prende-se com situações patológicas e potencialmente graves que exigem reconhecimento e tratamento célere.

\section{Fisiologia da Pele do RN}

A pele do RN providencia uma barreira entre o hospedeiro e o ambiente que o rodeia, na sua dimensão física, química e biológica. É responsável por funções de proteção mecânica,

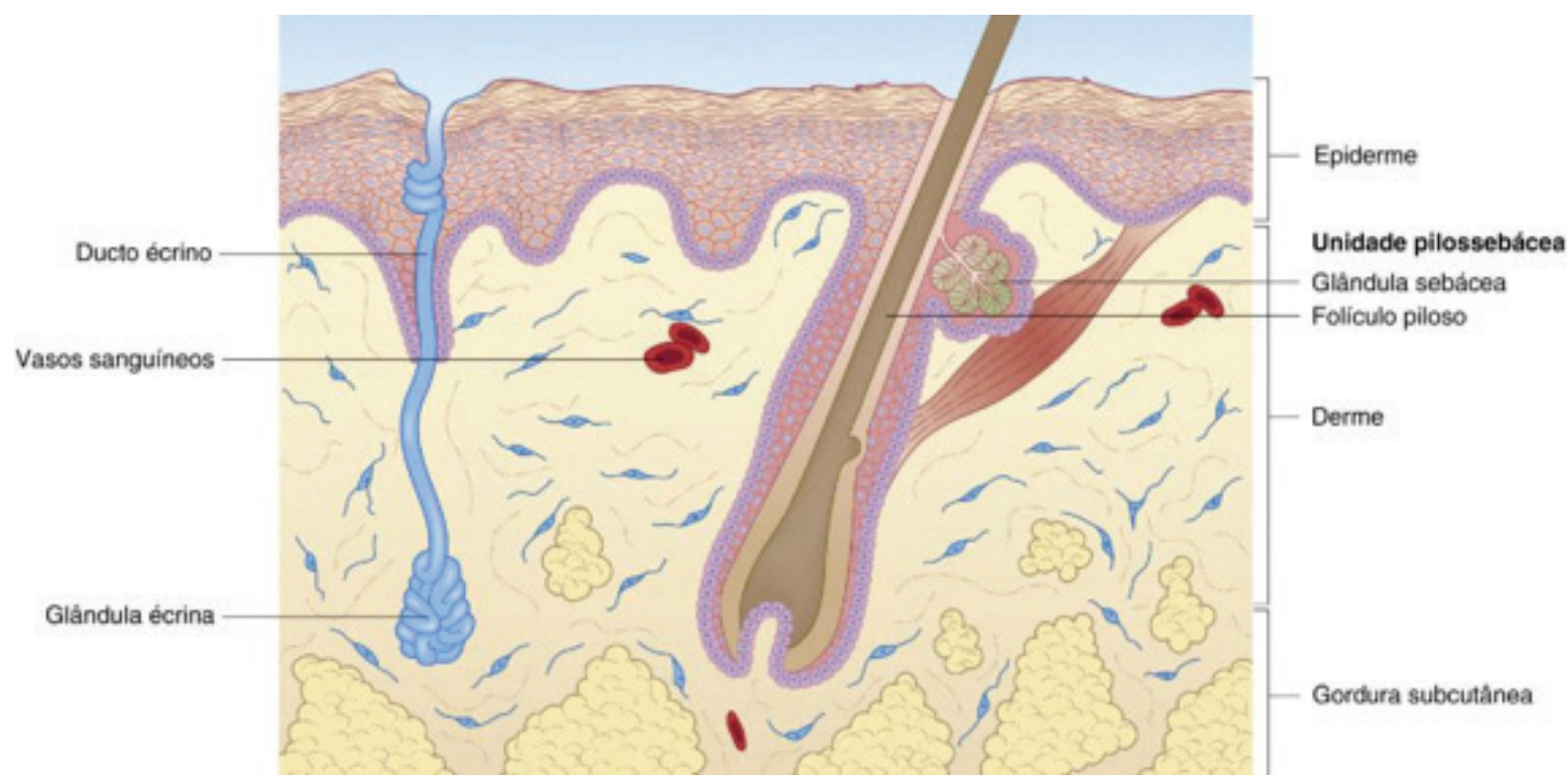

Figura 1. Corte transversal da superfície cutânea. São três as camadas que constituem a pele: epiderme (estrato córneo é o mais superficial), derme e a gordura subcutânea. 

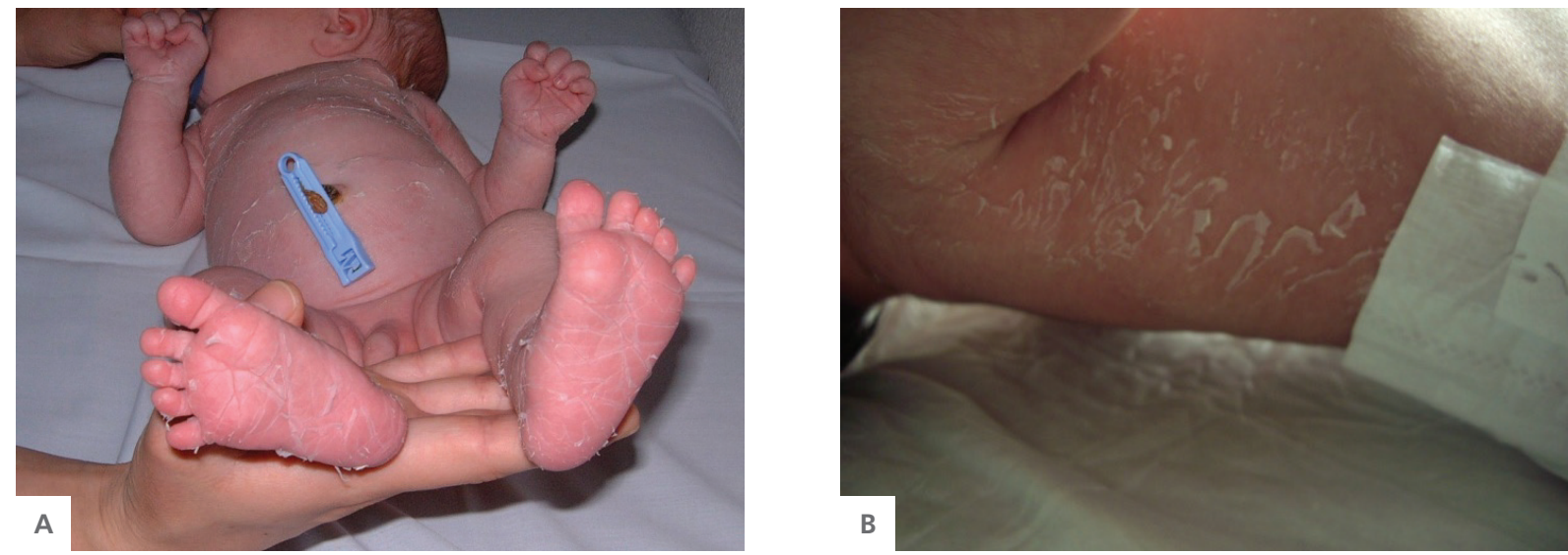

Figuras 2. Descamação fisiológica exuberante. Fotografia de Manuel Salgado e do autor.

termoregulação, imunovigilância e prevenção da perda de fluídos corporais, e é também uma potencial porta de entrada para agentes infeciosos, bem como alvo de agressão por agentes tóxicos.

É constituída por compartimentos individuais com tipos celulares específicos e estruturas diferenciadas das quais se destacam as unidades pilo-sebáceas, as glândulas sudoríparas, os nervos e a rede vascular, que têm papel anatómico e funcional na homeostase cutânea (figura 1).

A diferença mais evidente entre a pele do RN e a do adulto é a existência de uma substância esbranquiçada, húmida e gordurosa que é o vérnix caseoso. Esta substância persiste nos primeiros dias de vida.

O RN de termo tem uma pele que é histologicamente semelhante à do adulto. Possui uma epiderme com estrato córneo bem desenvolvido e com uma propriedade de barreira excelente (tal não acontece no RN pré-termo). A pele é contudo, mais sensível no período neonatal, o que se deve a uma fragilidade temporária da junção dermo-epidérmica que pode resultar na formação de bolhas e de erosões. As glândulas sebáceas encontram-se bem formadas e desenvolvidas na altura do nascimento sendo bastante ativas no período neonatal, principalmente quando sofrem estimulação pelas hormonas esteroides transplacentares e endógenas, resultando por exemplo, em situações benignas e transitórias como o aparecimento de acne neonatorum. Após o primeiro ano de vida assiste-se a um declínio progressivo na produção de sebo. Pelo contrário, as glândulas écrinas (sudoríparas) estão ainda numa fase imatura da sua evolução.

De seguida iremos descrever sumariamente as principais alterações cutâneas fisiológicas do RN.

\subsubsection{Vérnix caseoso}

Apresenta-se na superfície cutânea ao nascimento liberalmente disperso ou mais concentrado em áreas como as pregas inguinais e axilares, genitais e zonas retro-auriculares. Possui uma aparência esbranquiçada e uma consistência cremosa e é constituído por uma 


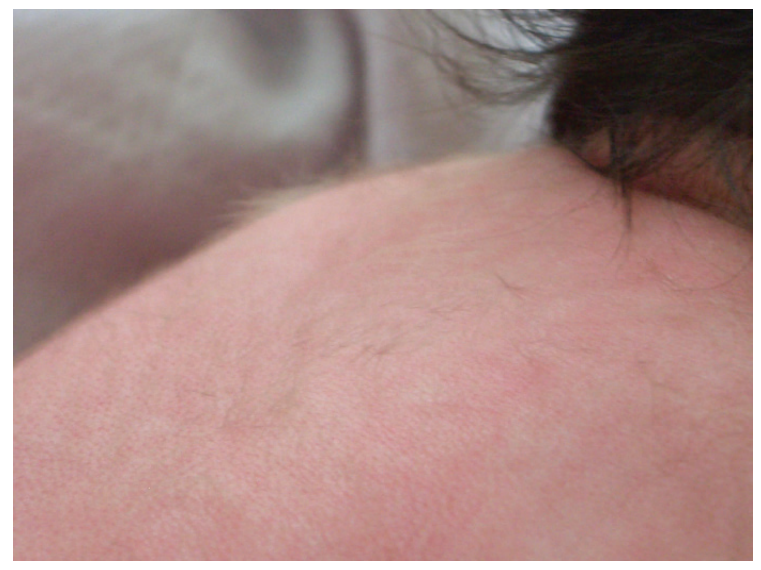

Figura 3. Lanugo no recém-nascido. Fotografia de Luís Januário.

mistura de células epiteliais que descamaram, sebo e por vezes cabelo. Tem funções de lubrificação e atua como barreira de permeabilidade na proteção da pele do líquido amniótico que a rodeia. A sua espessura aumenta com a idade gestacional, embora os RN pós-termo não se apresentem com vérnix, e a sua coloração alterada pode ser uma pista que denuncia sofrimento fetal.

\subsubsection{Descamação fisiológica}

A maioria dos RN de termo apresentará uma descamação fina da pele entre as 24 e as 48 horas de vida, geralmente localizada às mãos e aos pés (figuras 2, a) b)). No RN pré-termo, habitualmente esta descamação só será visível após ter completado duas a três semanas de vida. É porém no RN pós-termo que a descamação é mais exuberante ao nascimento, atingindo as mãos, os pés, o tronco inferior e a fronte. O diagnóstico diferencial inclui formas de ictiose bem como displasias ectodérmicas.

\subsubsection{Lanugo}

O lanugo corresponde ao pêlo, suave e delicado, não-pigmentado e sem medula central (figura 3). É o primeiro pêlo formado pelo folículo piloso fetal e possui dois períodos de crescimento que terminam em dois períodos de queda. O primeiro período de queda ocorre in-útero por volta dos sete a oito meses de gestação, e o segundo surge perto do termo da gestação ou mesmo após o nascimento. O lanugo é um indicador útil na determinação da idade gestacional, fazendo parte inclusivamente de algumas das escalas construídas com esse propósito (Ballard modificada). A presença de lanugo num RN é assim caraterístico do pré-termo onde se mostra exuberante, cobrindo os ombros e a totalidade do dorso. A parte distal dos membros é menos atingida. O envolvimento da face pode ser bilateral e extenso. Mais tarde o lanugo desaparece, em primeiro lugar na zona inferior do dorso e depois nas restantes. A substituição de lanugo por pêlo terminal ocorre nos primeiros meses de vida.

\subsubsection{Mancha mongólica}

Representa uma coleção de melanócitos muito alongados e fusiformes, localizados na derme e com disposição paralela à superfície cutânea. A sua incidência é variável nas várias etnias, sendo particularmente prevalente nos bebés AfroAmericanos (95,5 \%) e Asiáticos (81\%), enquanto nos Caucasianos é observada menos frequentemente $(9,6 \%)$. São máculas ou manchas de coloração cinzento-azulada ou negra que se localizam preferencialmente na zona lombo-sagrada e nadegueira, porém podem existir noutras regiões 


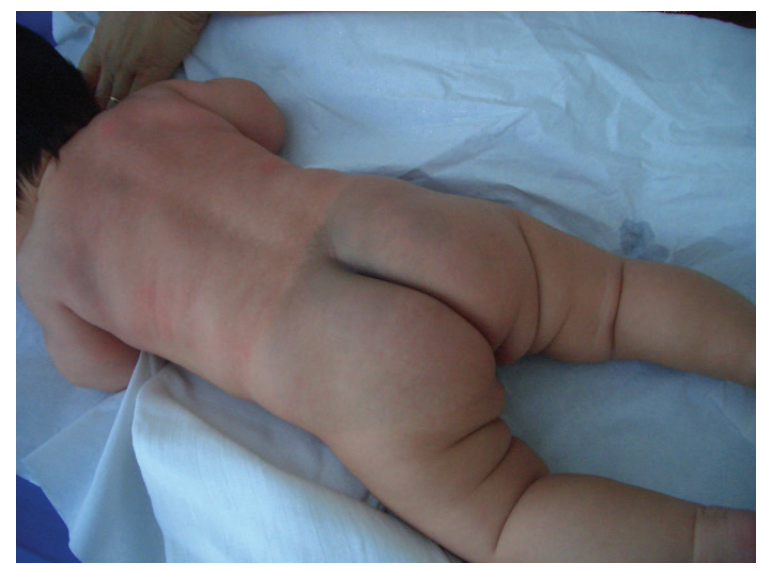

Figura 4. Mancha mongólica no recém-nascido com localização lombo-sagrada. Fotografia de Luís Januário.

como nos ombros e nos membros, podendo ser únicas ou múltiplas, medir poucos milímetros ou ultrapassar os dez centímetros (figura 4). A cor azulada da melanose dérmica é o resultado do efeito Tyndall (absorção da luz do comprimento de onda vermelho e reflexão da luz de comprimento de onda azul pelo pigmento melanínico que é castanho e profundo). O seu diagnóstico diferencial prende-se com outras formas de hiperpigmentação dérmica como os nevos de Ito (localizado nos braços ou nos ombros) e de Ota (localizado na região bucinadora ou no olho) ou com equimoses. Trata-se de uma situação benigna, cuja tendência é a de desaparecer por volta dos cinco anos se localizada às zonas típicas referidas, podendo persistir quando localizada noutras áreas.

\subsubsection{Hiperpigmentação dérmica}

Trata-se da coloração negra transitória que é observada na região genital (grandes lábios e escroto), em estrias lineares na região abdominal

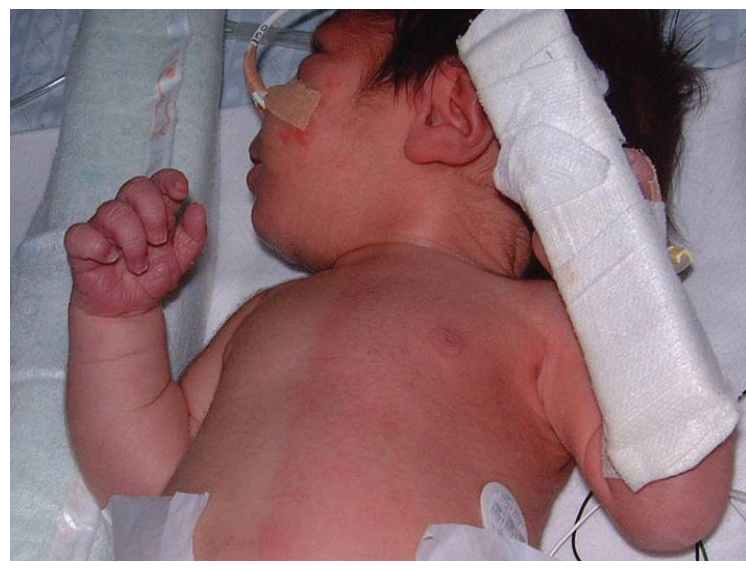

Figura 5. Recém-nascido com Arlequim. Fotografia de Manuel Salgado.

inferior (linha nigra), a rodear a aréola do mamilo, na axila e na base ungueal. É mais comum no RN de raça negra e tem um carácter transitório. Esta hiperpigmentação deve-se sobretudo à ação estimuladora da hormona melanocítica (MSH). Em certas ocasiões o padrão de hiperpigmentação não tem origem hormonal (hiperqueratose por trauma mecânico in-utero), o que se traduz na existência de bandas horizontais de hiperpigmentação no abdómen e no dorso. Este tipo de hiperpigmentação também é transitório. O diagnóstico diferencial faz-se sobretudo com a hiperplasia congénita da supra-renal que exige diagnóstico precoce, mas que se acompanha de um quadro clínico típico (ver lição de vómitos).

\subsubsection{Cutis marmorata e Arlequim}

A imaturidade do RN pode manifestar-se pela exibição de anomalias distintas do fluxo sanguíneo cutâneo. Assim a constrição capilar e venular, em resposta ao frio, produz um padrão violáceo reticulado típico, que quando ocorre 


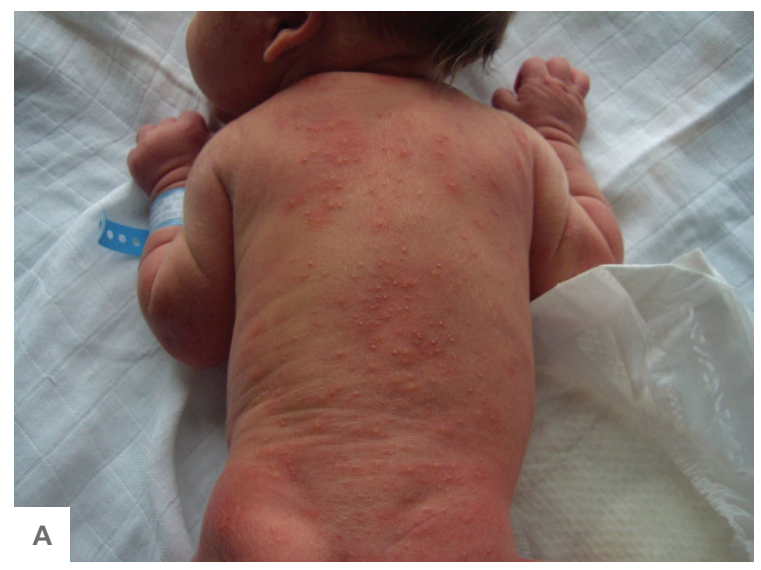

Figuras 6 a) b). Eritema tóxico do recém-nascido. Fotografias do autor.

em zonas mais acrais (distais) que centrais pode produzir uma coloração violácea intensa ou azul das mãos, pés e lábios - fenómeno conhecido como acrocianose. É típica do RN pré-termo, tendo caráter transitório e melhoria rápida após aquecimento. A sua tendência a recorrer diminui com a idade. O diagnóstico diferencial faz-se com situações patológicas como a cutis marmorata telangiectásica congénita e as cardiopatias congénitas cianóticas (cianose central).

Arlequim é um fenómeno raro em que a quantidade de fluxo sanguíneo difere marcadamente entre o lado direito e o esquerdo do corpo com demarcação evidente na linha média (figura 5). Ocorre quando o RN se encontra em decúbito lateral, em que o lado dependente exibe vasodilatação, sendo marcadamente mais vermelho que a metade superior. A face e os órgãos genitais podem ser poupados. Estes episódios duram segundos, mas podem ter uma duração de minutos, sendo facilmente reversíveis. O mecanismo fisiopatológico subjacente é a disautonomia autonómica,

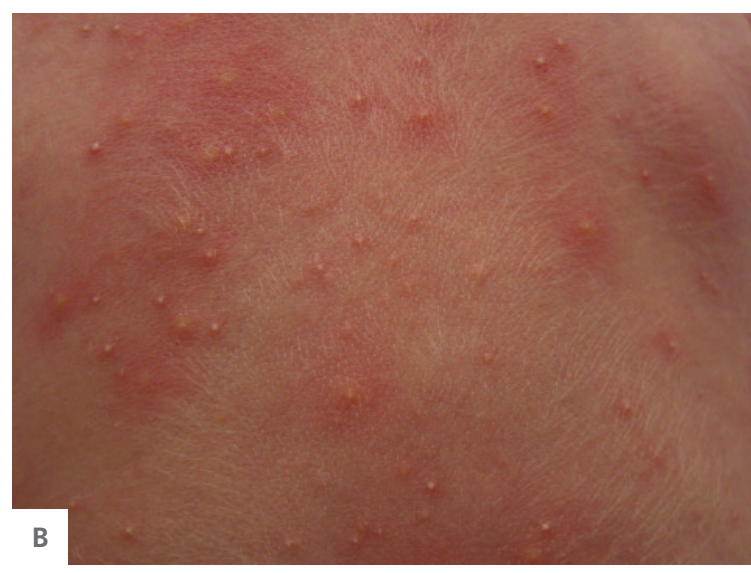

secundária a imaturidade hipotalâmica. Apesar de benigno a existência deste fenómeno para além do período neonatal deverá levar a uma investigação causal.

\subsubsection{Eritema tóxico neonatorum}

É considerada por muitos autores como a erupção benigna mais comum no período neonatal e pode existir em até metade dos RN de termo. Correlaciona-se com a idade gestacional e com o peso de nascimento, sendo raro em pré-termos e naqueles que nascem com menos de 2500 gramas. Surge habitualmente entre as primeiras 24 a 48 horas de vida, embora estejam descritos casos em que está presente ao nascimento e outros em que aparece após os dez dias de vida. Habitualmente as lesões desvanecem num período que poderá atingir os sete dias. A erupção clássica é a de uma mácula, pápula ou pústula amarelada com um a três milímetros de maior diâmetro que se encontra rodeada por um halo eritematoso irregular (figuras 6 a) b)). 


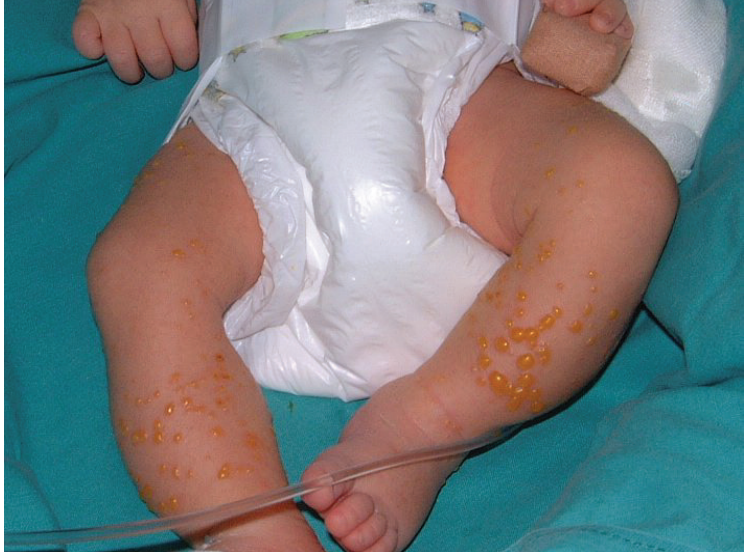

Figura 7. Impétigo estafilocócico do recém-nascido. Fotografia de Manuel Salgado.

Na maioria dos casos as lesões são discretas e dispersas, mas por vezes, observam-se casos exuberantes. Atinge a face e depois o tronco e as extremidades, mas pode surgir em qualquer local do corpo, exceto palmas e plantas. Histologicamente corresponde a pústulas eosinofílicas intrafoliculares que se localizam acima da entrada do ducto sebáceo. Postula-se que na sua origem fisiopatológica esteja uma reação do tipo enxerto-versus-hospedeiro contra os linfócitos maternos, mas tal hipótese não foi ainda completamente esclarecida. O diagnóstico é clínico, mas se houver dúvida poderá ser realizado um esfregaço que revelará a riqueza de eosinófilos nas lesões.

O diagnóstico diferencial faz-se com as alterações pustulares do RN, nomeadamente com a acropustulose infantil (a distribuição é mais acral que truncal), a infeção cutanêa por herpes simplex (carácter vesiculoso com formação subsequente de crostas), o impétigo estafilocócico (pústulas mais bem desenvolvidas e definidas - figura 7), a candidíase congénita (teste com hidróxido de potássio - $\mathrm{KOH}$ - é positivo e as lesões são mais descamativas), a melanose pustulosa neonatal transitória (sempre presente ao nascimento com desaparecimento rápido das pústulas deixando máculas pigmentadas, com esfregaço rico sobretudo em neutrófilos), e a miliária rubra (pode apresentar-se com pápulo-pústulas eritematosas, mas que predominam sobretudo na cabeça e no pescoço, sendo mais pequenas e sem halo eritematoso).

\subsubsection{Melanose pustulosa}

neonatal transitória

Ocorre sobretudo em Afro-Americanos de ambos os sexos, sendo que as lesões estão sempre presentes ao nascimento. É uma situação que ocorre tipicamente em RN de termo. São descritas três fases e portanto três tipos de lesões:

$1^{\text {a }}$-vésico-pústulas superficiais (com dois a dez milímetros de diâmetro) sem eritema circundante que podem estar presentes in-utero e virtualmente sempre ao nascimento. Após o nascimento não se desenvolvem habitualmente novas lesões, mas as originais podem progredir, formando uma crosta acastanhada, ou sofrer rutura deixando colar esbranquiçado e fino.

$2^{a}$ - colar fino esbranquiçado de escamas que rodeia a pústula em resolução.

$3^{a}$ - máculas hiperpigmentadas castanhas que surgem no local da pustulação prévia num período de dias (hiperpigmentação 
pós-inflamatória transitória). Alguns nascem com estas máculas (fase pustulosa presumivelmente in-utero).

Pode haver combinação das várias fases em dado período. A localização típica é em agregados infra-mentonianos, na fronte e zona retro-auricular, pescoço, tronco superior, região inferior das costas e nos membros (palmas e plantas também podem ser afetadas). O esfregaço do conteúdo pustular é estéril e mostra apenas neutrófilos com raros ou nenhuns eosinófilos. As pústulas tendem a resolver rapidamente, mas as máculas hiperpigmentadas podem demorar meses a desaparecer.

O diagnóstico diferencial inclui o eritema tóxico (aparece alguns dias após nascimento, é inflamatório e as vesículas contém predominantemente eosinófilos), acropustulose infantil (aparece mais tardiamente e predomina nas mãos e nos pés), impétigo estafilocócico, candidíase congénita (teste com $\mathrm{KOH}$ positivo, visualizando-se esporos e pseudohifas), miliária cristalina ou rubra (não deixa hiperpigmentação pós-inflamatória).

\subsubsection{Miliária}

É o termo geral utilizado para descrever a obstrução do ducto écrino cujas manifestações variam dependendo do local exato da obstrução. Tende a ocorrer em lactentes de climas quentes, naqueles mantidos artificialmente aquecidos e nos que estão febris. No período neonatal imediato a forma mais comum de miliária é a mais superficial - miliária cristalina (sudamina) - em que a obstrução ductal é sub ou intra-córnea, levando

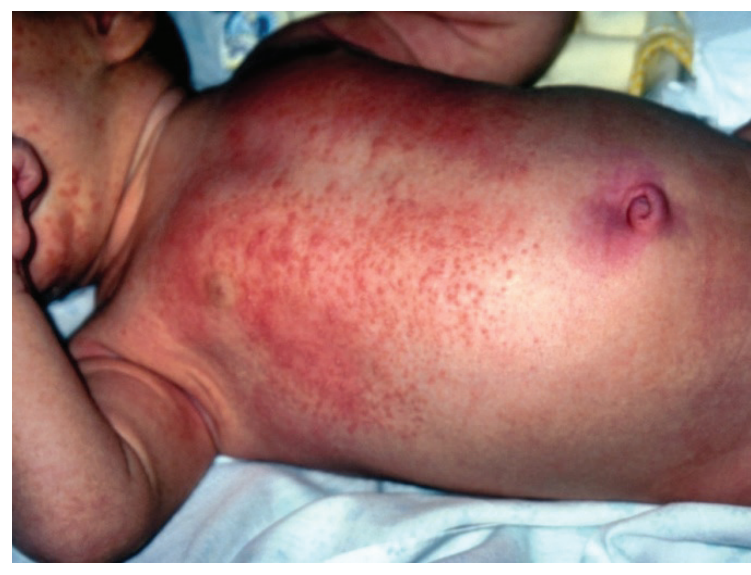

Figura 8. Miliária rubra. Fotografia de Manuel Salgado.

ao aprisionamento muito superficial de suor que produz as típicas pequenas vesículas cristalinas que mimetizam gotas de água na pele, de consistência frágil. Outra forma de miliária, também comum no período neonatal - miliária rubra - é característica do recém-nascido sobreaquecido e febril (heat rash), apresentando-se como pápulas ou pápulo-pústulas de um a três milímetros, eritematosas, localizadas preferencialmente na cabeça, pescoço, face e tronco (figura 8). Histologicamente existe inflamação dérmica com obstrução mais baixa do ducto écrino. A miliária profunda corresponde à manifestação objectiva da obstrução mais profunda do ducto sudoríparo localizada à junção dérmico-epidérmica ou mesmo abaixo dela. É uma situação rara no período neonatal. O diagnóstico diferencial das diferentes formas de miliária é variado mas o seu tratamento consiste apenas na correção do sobreaquecimento. 


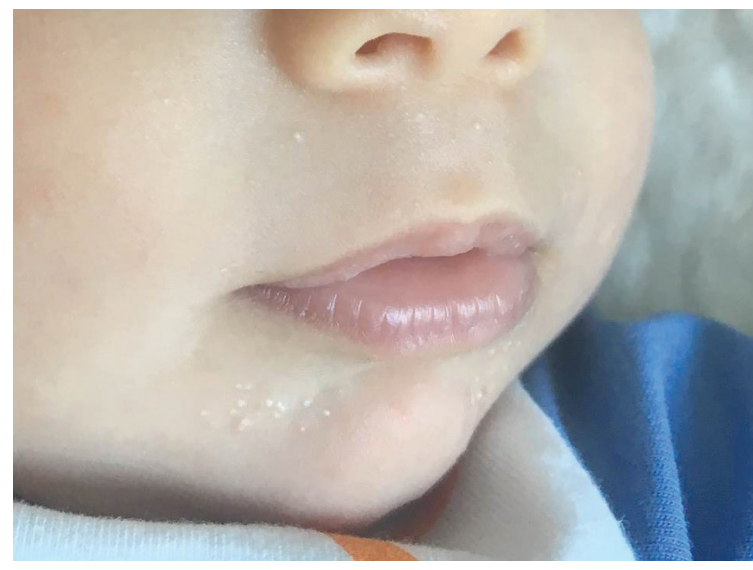

Figura 9. Mília. Fotografia do autor.

\subsubsection{Hiperplasia sebácea}

A hiperplasia das glândulas sebáceas é mais frequente nos RN de termo, ocorrendo em cerca de metade destes, mas também pode existir nos pré-termo, embora menos frequentemente. São pequenas pápulas que se agrupam caracteristicamente em placas, de aparência folicular e de consistência mole com coloração branco-amarelada. Localizam-se predominantemente na face, especialmente em redor do nariz e do lábio superior e não têm halo eritematoso. A sua predileção por estas zonas da pele prende-se com o facto de ser precisamente nestas áreas que a densidade de glândulas sebáceas é superior. A hiperplasia sebácea resulta da estimulação por androgéneos maternos ao nível do folículo pilo-sebáceo, que ocorre durante as semanas finais da gestação e que provoca um aumento no número e no volume das células sebáceas. O diagnóstico diferencial é com a mília, outra situação benigna, caracterizada por pequenas pápulas, maioritariamente solitárias e mais esbranquiçadas. Muitas vezes estas duas situações coexistem. Não é necessário qualquer tratamento para a hiperplasia sebácea assistindo-se à sua involução nas primeiras semanas a meses de vida.

\subsubsection{Mília}

A mília apresenta-se como pequenas pápulas, que medem até dois milímetros, que ocorrem primariamente na face e no couro cabeludo (figura 9). Possuem uma coloração esbranquiçada e têm superfície macia sendo normalmente discretas e existindo habitualmente em número reduzido. Podem estar presentes desde o nascimento ou aparecer posteriormente, e apesar de serem mais frequentes na face podem ocorrer em qualquer local do corpo. As pérolas de Epstein e os nódulos de Bohn são muito semelhantes à mília, embora ocorram na cavidade oral. Se localizados ao palato chamam-se pérolas de Epstein e quando se localizam nas pontes alveolares chamam-se nódulos de Bohn. A mília corresponde histologicamente a pequenos quistos de inclusão situados 
na epiderme e que contêm camadas concêntricas de estrato córneo queratinizado. O seu diagnóstico é clínico e o principal diagnóstico diferencial é com outra situação benigna, típica do período neonatal - a hiperplasia sebácea - que se caracteriza igualmente por pequenas pápulas brancas, embora com maior tendência a formar agregados à volta do nariz de coloração mais amarelada e que ocorrem em grandes placas. A resolução da mília é espontânea e tende a ocorrer ao longo de vários meses sem necessidade de qualquer tipo de intervenção.

\subsubsection{Bollhas de sucção}

As bolhas de sucção estão quase sempre presentes ao nascimento, podendo ser solitárias ou bilaterais. A lesão primária é uma bolha tensa que contém fluído e que se encontra rodeada por pele de aparência normal. A ruptura desta boIha resulta habitualmente em erosão. A etiologia destas lesões parece resultar do ato de sucção vigoroso e repetitivo, que acontece in-utero, numa localização particular. O diagnóstico é clínico e é evidenciado pelo comportamento de sucção que o RN exibe quando lhe é apresentada a extremidade atingida. A localização mais característica é, de longe, a superfície radial do punho, mas também podem existir no dorso da mão ou no dorso dos seus dedos.

\subsubsection{Ectasias capilares}

São máculas ou placas eritematosas que ocorrem na nuca "picadas de cegonha", pálpebras "beijos de anjo", glabela e mais raramente no nariz e no lábio superior (figuras 10 a) b)). Representam malformações vasculares minor, que histologicamente correspondem a capilares ectasiados na derme superior, recobertos por pele normal. São muito frequentes em Caucasianos, Latinos e Afro-Americanos, mas são raras em Asiáticos. A maioria resolve num período de meses a anos mas cerca de 25 a 50\% das lesões na nuca e uma percentagem menor das lesões na glabela podem persistir durante a vida. O diagnóstico diferencial 


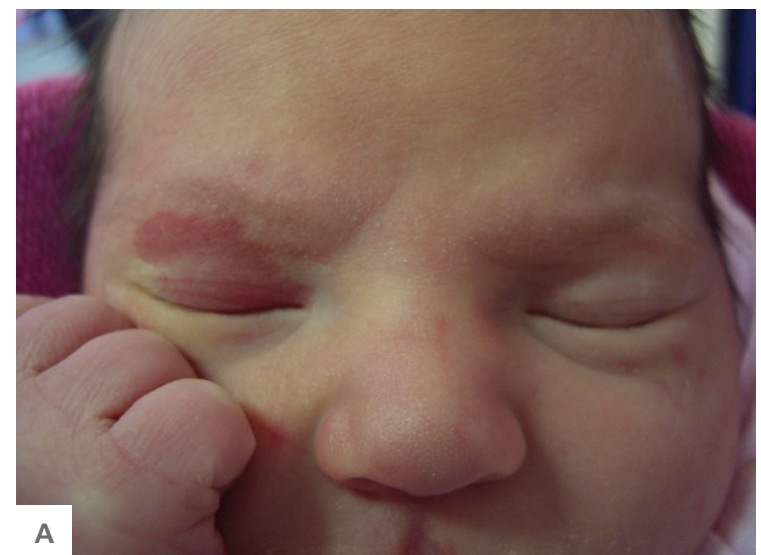

Figuras 10. Ectasias vasculares na pálpebra direita "beijos de anjo" (a) e na região da nuca "picadas de cegonha" (b). Fotografia do autor e de Manuel Salgado.

mais importante destas lesões transitórias são as manchas vinho-do-Porto cuja localização é mais lateral, não resolvem com a idade e muitas vezes continuam a escurecer e a aumentar de espessura, podendo estar associadas a patologia.

\section{Não esquecer}

A semiologia dermatológica durante o período neonatal é excecionalmente rica.

A ocorrência de dermatoses neste período é uma situação comum, sendo que a maioria destas é transitória, benigna e não exige qualquer tipo de tratamento.

O seu reconhecimento é fácil, embora por vezes, algumas das alterações cutâneas do RN possam ser o primeiro sinal de doença grave.

O diagnóstico correto e a identificação do tipo de dermatose em causa permite, em primeiro lugar, tranquilizar os pais mas também impedir o tratamento intempestivo e muitas vezes invasivo de situações fisiológicas benignas e transitórias.

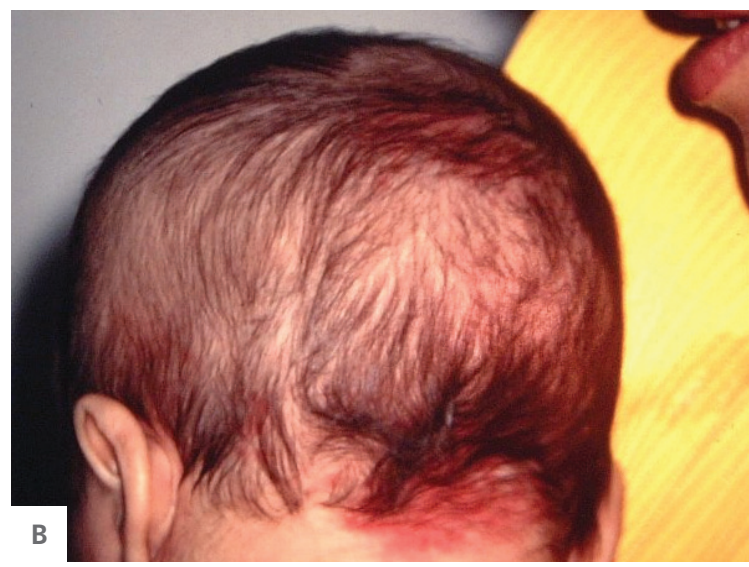

\section{Leitura complementar}

Lawrence F. Eichenfield et al. Neonatal and Infant Dermatology, 3rd Edition, 2015.

Josie A Pielop and Moise L Levy. Benign skin lesions in the newborn, UpToDate August, 2016.

Lawrence A. Schachner and Ronald C. Hansen. Pediatric dermatology, $3^{\text {rd }}$ Edition MOSBY 2003, Elsevier Limited. Januário G, Salgado M. The Harlequin phenomenon, J Eur Acad Dermato/ Venereol. 2011.

\subsubsection{Patologia mais comum}

\subsubsection{Eczema atópico}

O eczema atópico (EA), muitas vezes designado como dermatite atópica, é uma doença inflamatória crónica da pele cuja patogénese é complexa e envolve na sua origem factores ambientais, imunológicos e genéticos, que conduzem a disfunção da barreira cutânea e a desregulação do sistema imunitário. É a dermatose crónica mais comum em idade pediátrica, afetando cerca de dez a vinte por cento das crianças em países 
desenvolvidos, e caracteriza-se por períodos de "crise" em que há exacerbação da doença e outros de remissão espontânea. Frequentemente, pela sua gravidade e extensão, tem uma interferência negativa na qualidade de vida da criança e até dos seus cuidadores, levando a perturbação das atividades diárias e do sono. Por outro lado, tem um impacto económico significativo, não apenas pelos custos elevados da medicação diária mas também pelo absentismo escolar e laboral e procura frequente de cuidados médicos. Os avanços recentes no tratamento do EA têm-se focado na reparação da barreira epidérmica, uma vez que os estudos efetuados têm demonstrado a relevância de mutações genéticas com implicação funcional nas proteínas epidérmicas, nomeadamente a filagrina, resultando em pele seca e sensível.

\section{Diagnóstico}

O diagnóstico de EA é clínico e tem como base elementos da história clínica e do exame objectivo (quadro 1), tais como:

Idade de início das lesões cutâneas - o EA surge habitualmente entre os três e os seis meses de vida. Aproximadamente $60 \%$ dos doentes desenvolve lesões típicas no primeiro ano de vida e $90 \%$ fá-lo até aos cinco anos. A maioria dos indivíduos afetada ao atingir a idade adulta apresenta resolução da doença, embora cerca de 15\% mantenha sintomas e uma percentagem menor desenvolva a clínica apenas neste periodo.

Padrão de envolvimento cutâneo - as lesões que caracterizam o EA são lesões tipicamente pruriginosas (o prurido é um elemento fundamental para o diagnóstico) e exsudativas na fase aguda. Nas crianças com menos de dois anos localizam-se preferencialmente à face, deixando livre as regiões à volta do nariz e da boca, e às superfícies extensoras dos membros inferiores e superiores, poupando caracteristicamente a região da fralda. Após esta idade, o EA localiza-se sobretudo nas pálpebras, lábios e pescoço e tende a envolver as flexuras cubitais e poplíteas, atingindo também os tornozelos. Por vezes observamos também os aspectos crónicos das lesões de EA, nomeadamente a liquenificação que se carateriza pelo acentuar das pregas cutâneas. A existência de prurido e de pele seca (xerose), são elementos perenes do EA, na ausência de tratamento.

\section{Existência de história pessoal ou fami-} liar de atopia - 50 a 60\% dos doentes com EA tem um familiar de primeiro grau com EA, asma ou rinite. Deverá ser pesquisada a existência de potenciais factores desencadeantes ou exacerbadores (história alimentar e potencial de alergia alimentar, aeroalergenos, alergenos de contacto e irritantes), classificada a gravidade da doença, e a resposta a tratamentos atuais e/ou prévios. O impacto na criança, pais ou cuidadores e a avaliação do neurodesenvolvimento e crescimento fazem parte da avaliação inicial do EA.

\section{Tratamento}

O tratamento do EA tem como objetivos principais a redução ou eliminação dos sinais e sintomas da doença e a prevenção ou diminuição das recidivas. Visa igualmente providenciar medidas preventivas de exacerbação a longo prazo e modificar o curso natural da doença. Qualquer tipo de tratamento deve ser sempre acompanhado de medidas de eliminação de factores que contribuem para potenciar a 


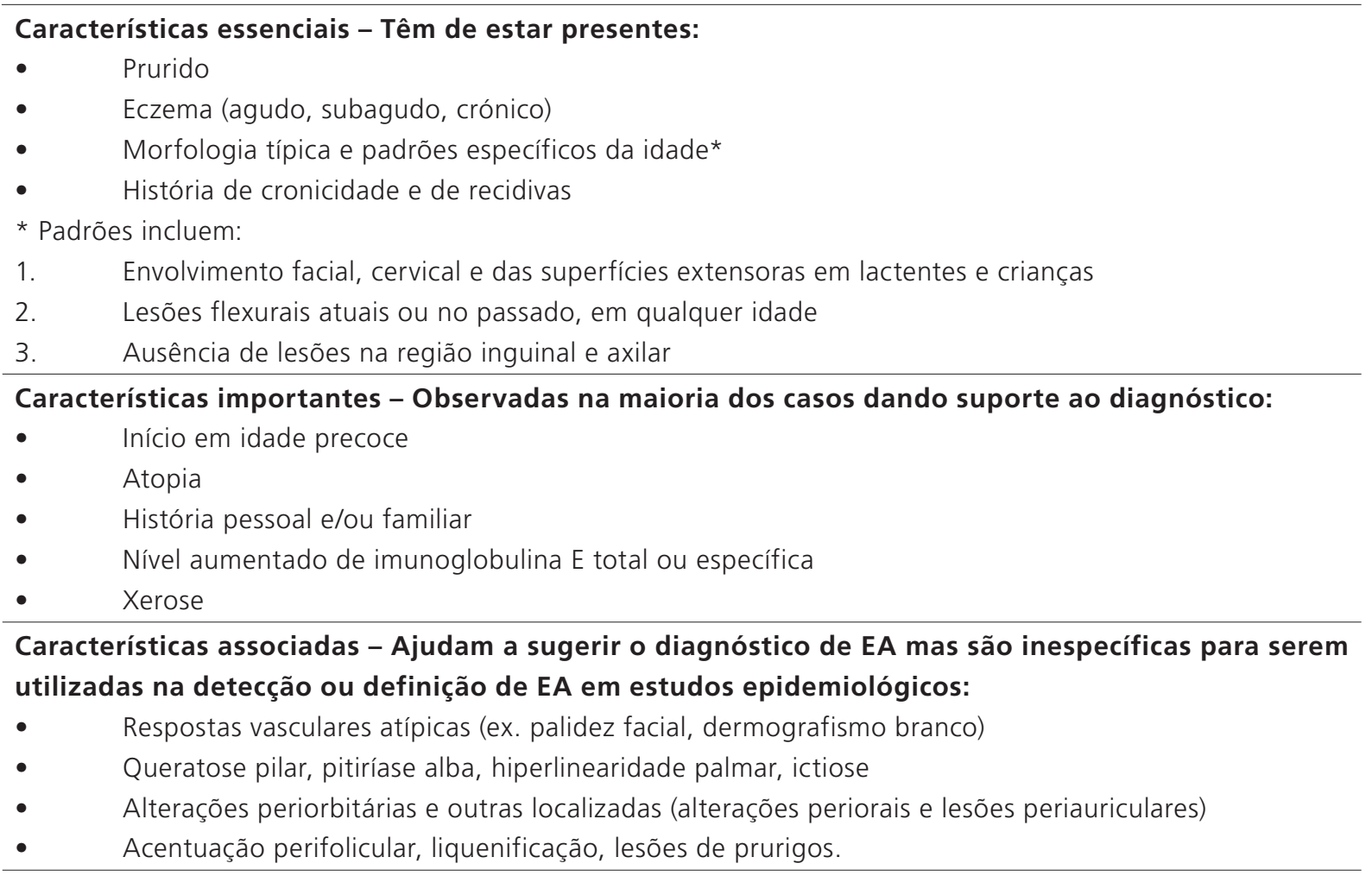

\section{Condições que excluem EA - Doenças que fazem diagnóstico diferencial com EA:}

- Escabiose

- $\quad$ Eczema seborreico

- $\quad$ Eczema de contacto

- Ictioses

- $\quad$ Psoríase

- Imunodeficiência

Legenda. EA- eczema atópico

Quadro 1. Diagnóstico do Eczema Atópico.

exacerbação ou agravamento do EA, nomeadamente os banhos excessivos e prolongados, ambientes de baixa humidade, stresse emocional, a xerose cutânea, o sobreaquecimento da pele e a exposição a detergentes e solventes. A evicção destas situações é benéfica na redução do número de exacerbações agudas bem como no controle da doença a longo-prazo.
A roupa aconselhada é a de algodão devendo evitar-se a de lã e os produtos sintéticos. O calçado deve ser arejado.

O controlo do prurido pode ser um desafio e muitas vezes é necessário recorrer aos anti-histamínicos H1 por via oral, quando a hidratação cutânea com emolientes e hidratantes não é suficiente para a sua acalmia. Muitas vezes é 


\begin{tabular}{|c|c|c|}
\hline Eczema atópico ligeiro & Eczema atópico moderado & Eczema atópico grave \\
\hline Emolientes & Emolientes & Emolientes \\
\hline \multirow{5}{*}{$\begin{array}{l}\text { Corticoides tópicos de } \\
\text { baixa potência }\end{array}$} & $\begin{array}{l}\text { Corticoides tópicos de } \\
\text { moderada potência }\end{array}$ & Corticoides tópicos potentes \\
\hline & Inibidores tópicos da calcineurina & Inibidores tópicos da calcineurina \\
\hline & \multirow{3}{*}{ Pensos } & Pensos \\
\hline & & Fototerapia \\
\hline & & Terapêutica sistémica \\
\hline
\end{tabular}

Quadro 2. Abordagem escalonada do eczema atópico.

necessário recorrer a anti-histamínicos sedativos como a hidroxizina, o dimentideno, ou a oxatomida. No caso de surgirem os seus efeitos secundários, nomeadamente sonolência exagerada, deverá ser ponderada a utilização de anti-histamínicos não sedativos como a loratadina, desloratadina, lexocetirizina ou ebastina. Os anti-histamínicos

\section{tópicos estão proscritos .}

Os profissionais de saúde deverão utilizar uma abordagem terapêutica escalonada e adequar a potência do tratamento à gravidade do EA (Quadro 2).

\section{- Emolientes}

A hidratação cutânea é o componente chave do tratamento do EA, motivo pelo qual os emolientes são usados em todas as fases de intervenção, inclusivamente quando não existem quaisquer lesões e a pele está aparentemente sã. Vários estudos têm comprovado que os emolientes reduzem a necessidade de tratamento com corticoides tópicos e deverão ser utilizados liberalmente, pelo menos duas a quatro vezes por dia, devendo estar disponíveis na escola, infantário ou em qualquer outro local que a criança frequente com regularidade. Os emolientes devem igualmente ser aplicados imediatamente após o banho, em pele ainda ligeiramente húmida, aproveitando a maior capacidade de absorção. O banho deve ser realizado preferencialmente ao final do dia (para maximizar o tempo de aplicação e de permanência do emoliente em contacto com a pele), ser de duração curta e com utilização de água morna. Está disponível uma gama extensa de emolientes adequados ao tratamento do EA e todas as marcas comerciais têm disponíveis produtos de higiene indicados no EA, caso dos pains (leites sólidos que servem de sabonete), syndets (detergentes sintéticos com tensoactivos suaves) e dos surgras (associação de ácidos gordos ao sabão).

\section{- Corticoides Tópicos}

Os corticoides (CT) tópicos, também chamados de dermocorticoides, têm uma ação anti-inflamatória não-seletiva. A sua utilização é muitas vezes necessária para controlo eficaz das lesões de EA, quando a ação dos emolientes se revela insuficiente. É importante realçar que a absorção dos CT tópicos depende da formulação (cremes menos absorvidos que pomadas) e do local onde são aplicados (quadro 3). Na 


\begin{tabular}{|l|}
\hline Diferenças regionais de penetração \\
\hline Membranas mucosas \\
\hline Escroto \\
\hline Pálpebras \\
\hline Face \\
\hline Tronco \\
\hline Metade proximal dos membros \\
\hline Metade distal dos membros \\
\hline Dorso das mãos e dos pés \\
\hline Pele palmoplantar \\
\hline Unhas \\
\hline
\end{tabular}

Quadro 3 - Diferenças na penetração dos corticoides tópicos por ordem decrescente.

criança, os CT tópicos utilizados deverão ser os de mais baixa potência possível e a sua aplicação na região da face e das pregas (zonas de absorção elevada) deverá ser realizada com particular atenção e cuidado. A zona da face, incluindo as pálpebras, tem uma maior penetração comparativamente ao tronco e aos membros, pelo que deve ser evitada a aplicação de CT tópicos mais potentes nesta área, bem como limitada a sua duração. Preferencialmente deverá ser utilizada a hidrocortisona a 1\%, o aceponato de metilprednisolona ou a mometasona.

Os CT tópicos devem ser aplicados em esquemas de curta duração, directamente sobre as lesões de eczema, uma a duas vezes por dia (preferencialmente à noite após o banho), durante cinco a sete dias. Após este período poder-se-á combinar o CT tópico com o creme hidratante, em proporções iguais de modo a que a quantidade de CT a aplicar seja metade da do período anterior, e aplicar durante cinco a sete dias novamente, efetuando assim o desmame. A quantidade de CT tópico a aplicar é também importante. Um sistema de quantificação fácil de utilizar é o da fingertip unit (FTU), em que a quantidade de creme colocada na falange distal de um dedo adulto corresponde a uma FTU, sensivelmente 0,5 gramas de creme.

A quantidade de creme ou pomada a aplicar está estabelecido consoante as zonas afetadas.

- Inibidores Tópicos da Calcineurina

Os inibidores tópicos da calcineurina (ITC) são fármacos de segunda linha no tratamento do EA e não estão recomendados no tratamento das formas ligeiras. A sua utilização reserva-se aos casos em que há falência do tratamento com a corticoterapia tópica ou quando há efeitos secundários importantes dos CT tópicos, tais como atrofia cutânea ou existência de estrias. Contrariamente aos CT tópicos, os ITC não induzem atrofia cutânea, e podem ser usados em todo o tegumento, incluindo a face, local particularmente sensível à aplicação crónica de CT tópicos. O tacrolimus, na concentração de 0,03\%, é o fármaco habitualmente utilizado e é o protótipo de ITC, não sendo 
recomendada a sua aplicação em crianças com menos de dois anos. A pomada deve ser aplicada, duas vezes por dia durante um período máximo de três semanas, e depois uma vez por dia, até ao desaparecimento da lesão. O pimecrolimus na concentração de $1 \%$ é outra alternativa. Os ITC são fármacos caros e não devem ser utilizados como primeira linha. Na sequência da notificação de casos de cancro de pele e linfoma em doentes que tinham utilizado estes fármacos, a Agência Europeia do Medicamento realizou uma reavaliação do seu perfil de segurança e concluiu que o benefício associado à sua utilização é superior ao risco, não tendo sido possível estabelecer uma relação causal entre a utilização dos ITC e o aparecimento de cancro de pele e linfoma. Recomendase que só os médicos com experiência, quer no diagnóstico quer no tratamento do EA, deverão iniciar terapêutica com estes fármacos e que a sua utilização contínua e prolongada deve ser evitada, suspendendo o tratamento logo que o eczema desapareça.

\section{- Tratamento da infeção}

Os doentes com EA têm um risco aumentado de infeções cutâneas bacterianas, virais e fúngicas. A sobreinfeção bacteriana, sobretudo por Staphylococcus aureus, mas também por Streptococcus pyogenes, é uma das causas mais comuns de exacerbação aguda do EA ou de falência do tratamento, devendo ser sempre identificada e tratada (figura 11).

O Staphylococcus aureus coloniza frequentemente a pele dos doentes com EA podendo ser isolado na pele em 76 a 90\% dos doentes (versus dois a $25 \%$ nos indivíduos sem EA). As maiores taxas de colonização são provavelmente secundárias

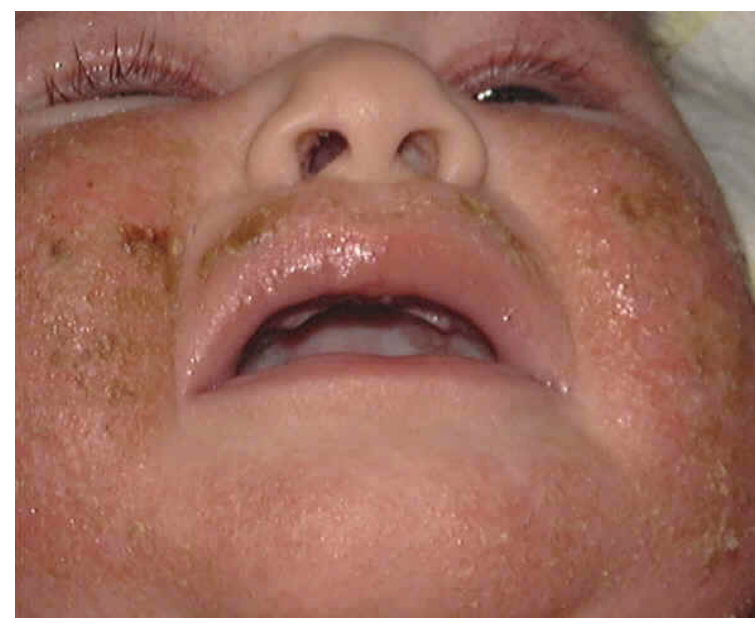

Figura 11. Lesão de eczema facial com sobreinfecção bacteriana. Fotografia do autor.

à alteração da barreira epidérmica e à redução de péptidos antimicrobianos cutâneos. As infecções por Staphylococcus aureus meticilino- resistentes (SAMR) têm aumentado na população geral em alguns países, nomeadamente nos Estados Unidos da América, mas apenas uma minoria dos doentes com EA estão colonizados com SAMR. Os doentes com EA e com sinais de infecção cutânea devem ser tratados com antimicrobianos. Os sinais de infecção incluem a existência de lesões exsudativas e/ou crostosas amareladas e de foliculite. A mupirocina e o ácido fusídico são eficazes no tratamento tópico destas infecções sendo indicada a utilização de penicilinas resistentes às penicilinases por via oral, como a flucloxacilina, no tratamento de infecções mais extensas. Não é recomendado o uso de antibióticos se não houver sinais clínicos de infecção.

O Eczema herpético corresponde à sobreinfecção das lesões de EA por Herpes Simplex tipo 1. Quando se localiza na face e envolve a região 


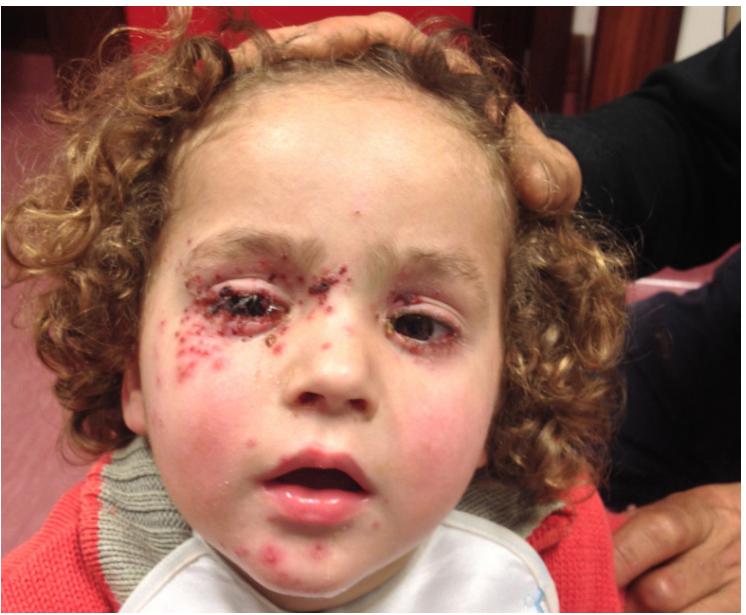

Figura 12. Eczema herpético envolvendo região ocular direita. Fotografia do autor.

ocular constitui uma urgência médica devendo ser tratado com aciclovir endovenoso, motivo pelo qual deverá ser referenciado a um serviço de urgência Pediátrico (figura 12). A maioria dos profissionais de saúde utiliza aciclovir sistémico no tratamento do eczema herpético, independentemente da sua localização.

\section{Critérios de envio à Consulta de Dermatologia}

A maior parte das situações de EA pode ser orientada em cuidados de saúde primários pelo médico de Medicina Geral e Familiar e pelo Pediatra, no entanto a referenciação à consulta de Dermatologia Pediátrica deverá ser considerada quando houver dúvidas no diagnóstico, quando o EA se localiza na face e é resistente ao tratamento instituído, se houver suspeita de dermatite de contacto alérgica, na presença de infeções recorrentes ou de alterações hematológicas e na ausência de resposta à terapêutica de primeira linha.

\subsubsection{Eczema seborreico e crosta láctea}

O eczema seborreico (ES) tem habitualmente início mais precoce que o EA, sendo mais frequente entre as quatro e as seis semanas de vida. Atinge primariamente o couro cabeludo, formando a crosta láctea, e as áreas intertriginosas, nomeadamente as pregas cervicais e retroauriculares, as axilas, o pescoço e umbigo. Ao contrário do EA, o ES não poupa o maciço centro-facial e as lesões são menos inflamatórias. Pode afetar a região da fralda com atingimento característico das pregas e envolvimento posterior das superfícies convexas, e contrariamente à dermatite das fraldas candidiásica não apresenta lesões satélites. Outra característica distintiva, em relação ao EA, é ausência de prurido e de irritabilidade. As crianças com ES normalmente alimentam-se sem qualquer dificuldade.

A característica crosta láctea do ES surge habitualmente semanas após o nascimento e é geralmente limitada aos três primeiros meses de vida. Visualizam-se escamas leves e untosas, aderentes ao vértex e à fontanela anterior, que se podem estender a todo o couro cabeludo, podendo inflamar e exsudar, resultando numa escama coerente que pode cobrir a maioria do couro cabeludo (figuras 13, a) b) c)). Não necessita habitualmente de medidas agressivas de tratamento podendo instituir-se apenas cuidados locais simples, nomeadamente de emolientes ou mousses e champôs suaves recomendados para a remoção de crostas e escamas do couro cabeludo. Não é aconselhada a utilização de champôs queratolíticos ou a remoção mecânica agressiva.

\subsubsection{Dermatite das fraldas}

A dermatite das fraldas (DF) é uma dermatose exclusivamente localizada, pelo menos inicialmente, 
à área coberta pela fralda, e ocorre nos períodos da vida em que a mesma é utilizada. A DF não deve ser interpretada como uma entidade diagnóstica específica, mas sim como um termo lato que designa um diagnóstico topográfico e que engloba um amplo grupo de dermatoses de etiologia multifactorial, nomeadamente a DF irritativa primária (a forma mais comum), a dermatite de contacto alérgica (muito rara), dermatites exacerbadas pelo uso de fraldas (EA e ES, psoríase, dermatite candidiásica) e dermatites que não se relacionam com o uso de fraldas (acrodermatite enteropática, histiocitose de Langerhans, dermatite estreptocócica perianal e impétigo bolhoso).

\section{- Dermatite da Fralda Irritativa Primária}

Trata-se da forma mais comum de DF e afeta 25 a $65 \%$ das crianças entre os seis e os 12 meses de idade. A conjugação de vários factores, nomeadamente a oclusão resultante do uso de fraldas aliada à fricção, à humidade e à temperatura aumentada levam a uma perda da integridade da barreira cutânea. A existência de fezes e urina conduz a uma irritação química e aumenta a agressão numa pele já lesada. Ao exame objetivo surge um eritema brilhante, confluente com aspecto "envernizado", que varia de intensidade ao longo do tempo. Por vezes apresenta-se na forma de pápulas eritematosas associadas a edema e a ligeira descamação. Atinge tipicamente as áreas de maior contacto com a fralda - "dermatite em W " (figura 14) - isto é, as superfícies convexas das nádegas, coxas, parte inferior do abdómen, púbis, grandes lábios e escroto. As pregas são inicialmente poupadas.

A complicação mais frequente da DF irritativa primária é a sobreinfeção, nomeadamente por
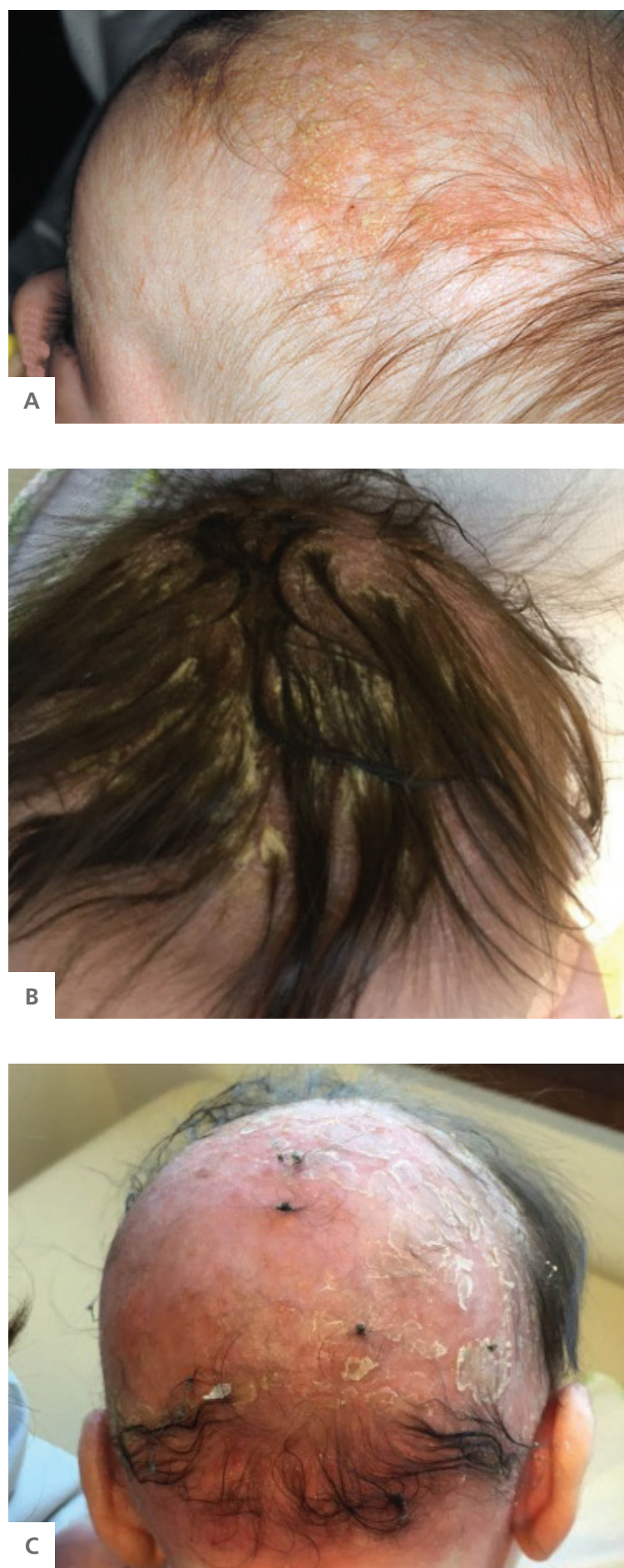

Figuras 13 a) b) c) - Crostas lácteas exuberantes com escamas aderentes e com zonas de alopécia. Fotografias do autor. 


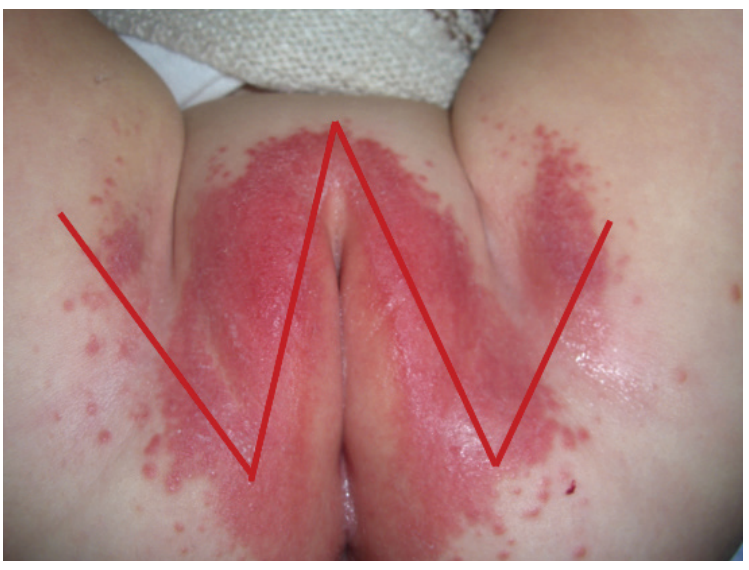

Figura 14. Dermatite da Fralda Irritativa Primária. Fotografia do autor.

Candida albicans. O ambiente húmido e quente favorece a proliferação desta levedura que ao penetrar o estrato córneo, activa a via alterna do complemento e induz um processo inflamatório, com alteração do aspecto da dermatose em que surge descamação, pápulas, pústulas e atingimento das pregas (figura 15). A diarreia crónica ou o uso de antibioterapia de largo espetro são duas situações que frequentemente favorecem a infeção por Candida albicans.

No quadro 4 é apresentado o diagnóstico diferencial de algumas patologias que podem causar DF.

O tratamento da DF tem como objetivos manter a área seca, limitar a mistura e a dispersão da urina e das fezes, reduzir o seu contacto com a pele, evitar a irritação e a maceração e manter, sempre que possível, um pH ácido, respeitando a máxima

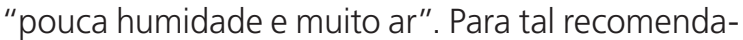
-se mudanças frequentes da fralda e expor a zona

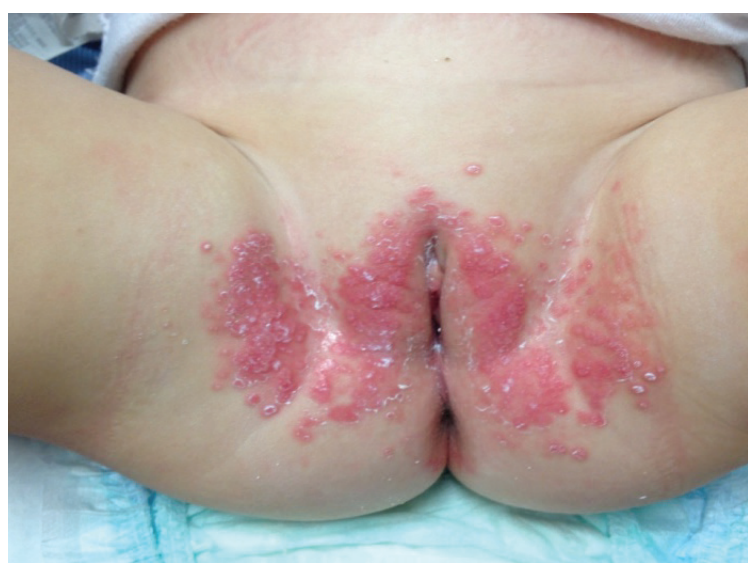

Figura 15. Dermatite da fralda candidiásica. Fotografia do autor.

afetada ao ar, se a temperatura ambiente o permitir. A higiene diária deverá consistir na lavagem da região com água morna e algodão e na utilização de produtos de ação suave e com efeito emoliente, não se recomendando, por rotina, toalhetes de limpeza uma vez que poderão ser irritantes. Poderse-á igualmente aplicar, em cada muda de fralda, um creme barreira ou uma pasta com óxido de zinco. As preparações com ácido bórico e pó de talco deverão ser evitadas pela sua toxicidade e capacidade de provocar granulomas. O controlo da sobreinfeção é fundamental mas não deverão ser utilizados antimicrobianos de forma "preventiva" e a infeção por Candida albicans deverá apenas ser considerada em dermatites com mais de três dias de evolução e sob as medidas recomendadas. O tratamento da DF candidiásica consiste na aplicação tópica de nistatina ou derivados do imidazol.

\subsubsection{Hemangiomas Infantis}

Os hemangiomas infantis (HI) são os tumores de tecidos moles mais comuns na infância. 
Trata-se de uma proliferação benigna do tecido endotelial que ocorre entre quatro a dez por cento das crianças com idade inferior a um ano (figuras 16 a) b)). São mais frequentes em caucasianos, no sexo feminino, em prematuros e nos recém-nascidos de baixo peso. A biopsia das vilosidades coriónicas constitui igualmente um factor de risco para o seu aparecimento. Caracterizam-se por um perfil evolutivo e um padrão de crescimento típicos. Estão geralmente ausentes ao nascimento, embora em alguns casos possa estar presente uma lesão precursora, sendo evidentes nas primeiras semanas de vida assistindo-se então a uma fase de crescimento rápido que dura habitualmente três a seis meses mas que se pode prolongar até aos 24 meses. Segue-se então um período de estabilização e de involução espontânea, que é lenta e gradual e que não deixa habitualmente sequelas (redundância cutânea, telangiectasias e tecido fibroso). Apesar de serem muitas vezes causadores de stresse familiar, exacerbado pelo uso incorreto por parte dos pais e cuidadores da informação disponível on-line, os HI têm, na maioria das situações, um prognóstico excelente e uma resolução espontânea com bom resultado cosmético.

\begin{tabular}{|c|c|c|c|}
\hline Dermatite & Morfologia & Localização & História \\
\hline Irritativa Primária & $\begin{array}{l}\text { Eritema brilhante, confluente de } \\
\text { aspecto envernizado. Por vezes } \\
\text { pápulas eritematosas associadas } \\
\text { a edema e ligeira descamação. }\end{array}$ & $\begin{array}{l}\text { Superfícies convexas das } \\
\text { nádegas, coxas, parte } \\
\text { inferior do abdómen, } \\
\text { púbis, grandes lábios e } \\
\text { escroto. Poupa as pregas. }\end{array}$ & $\begin{array}{l}\text { Evolução por surtos. História } \\
\text { de diarreia recente. Muda de } \\
\text { fraldas pouco frequentes. }\end{array}$ \\
\hline Candidiásica & $\begin{array}{l}\text { Eritema vermelho e vivo } \\
\text { com descamação periférica } \\
\text { ou pústulas satélites. }\end{array}$ & Pregas cutâneas atingidas. & $\begin{array}{l}\text { Antibioterapia ou diarreia. } \\
\text { Pesquisar atingimento } \\
\text { concomitante da } \\
\text { cavidade oral. }\end{array}$ \\
\hline Seborreica & $\begin{array}{l}\text { Placas descamativas, } \\
\text { bem delimitadas de } \\
\text { tonalidade salmão. Presença de } \\
\text { escamas gordas amareladas. Ao } \\
\text { contrário da candidiásica não } \\
\text { apresenta lesões satélites. }\end{array}$ & $\begin{array}{l}\text { Pregas cutâneas atingidas } \\
\text { e envolvimento posterior } \\
\text { das superfícies convexas. } \\
\text { Couro cabeludo, face, } \\
\text { pregas retroauriculares, } \\
\text { axilas, pescoço e umbigo. }\end{array}$ & $\begin{array}{l}\text { Assintomática, raramente } \\
\text { queixas de prurido. } \\
\text { Surge após o nascimento } \\
\text { (primeiros três meses de } \\
\text { vida). Geralmente com boa } \\
\text { resposta ao tratamento. }\end{array}$ \\
\hline Impétigo Bolhoso & $\begin{array}{l}\text { Bolhas flácidas e grandes que surgem } \\
\text { em pele aparentemente normal. Após } \\
\text { ruptura da bolha, surgem erosões } \\
\text { vermelhas e húmidas com formação } \\
\text { posterior de crostas melicéricas. } \\
\text { Pode ocorrer disseminação rápida } \\
\text { para outros locais do corpo. }\end{array}$ & $\begin{array}{l}\text { Múltiplas lesões } \\
\text { envolvendo as } \\
\text { coxas, nádegas e } \\
\text { abdómen inferior. }\end{array}$ & $\begin{array}{l}\text { Coloração pelo } \\
\text { Gram e cultura. }\end{array}$ \\
\hline $\begin{array}{l}\text { Dermatite } \\
\text { Estreptocócica } \\
\text { peri-anal }\end{array}$ & $\begin{array}{l}\text { Eritema vivo, bem } \\
\text { demarcado, perianal. } \\
\text { Pode ocorrer fissuração peri-anal. }\end{array}$ & $\begin{array}{l}\text { História de prurido e dor } \\
\text { durante a defecação. } \\
\text { História familiar de faringites } \\
\text { estreptocócicas de repetição. }\end{array}$ & $\begin{array}{l}\text { Cultura de zaragatoa } \\
\text { peri-anal. }\end{array}$ \\
\hline
\end{tabular}

Quadro 4. Diagnóstico diferencial de dermatite das fraldas. 

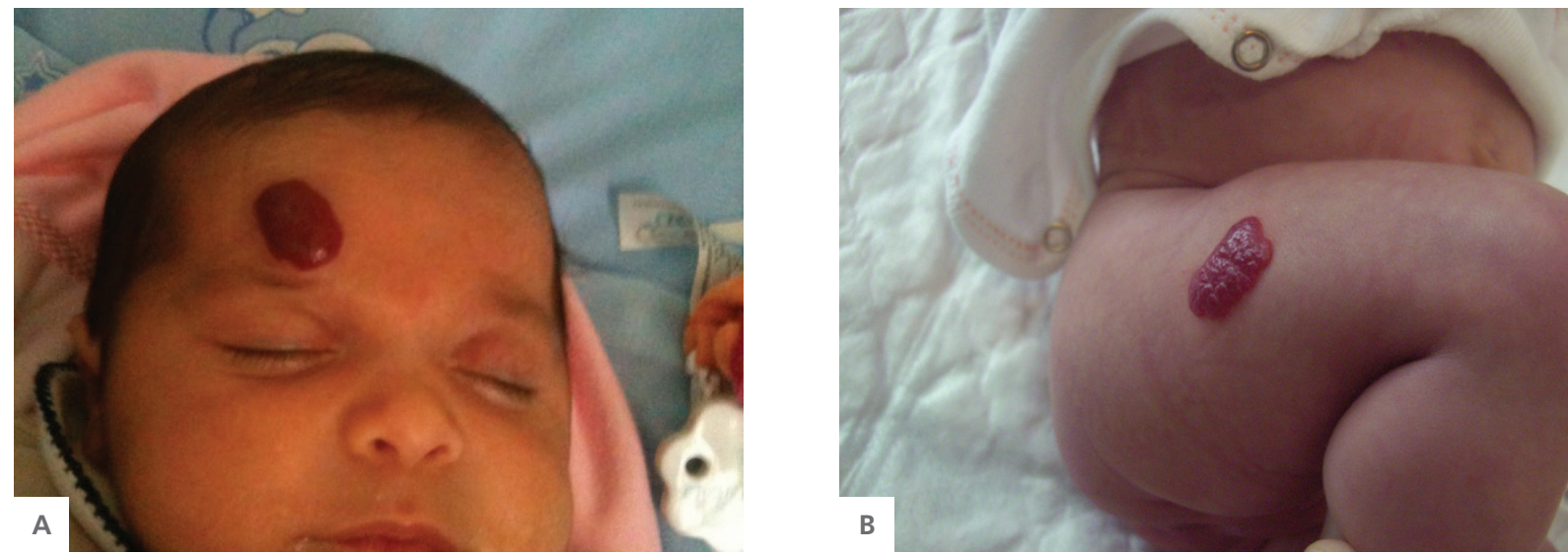

Figuras 16 a) b). Hemangiomas infantis da fronte (a) e da coxa direita (b).

Fotografias do autor.

Em cerca de $10 \%$ dos lactentes com HI poderá ser necessário instituir algum tipo de tratamento, para além da vigilância habitual. Assim preconiza-se intervenção terapêutica no caso de HIs com risco de vida associado (localização nas vias respiratórias superiores e hemangiomatose hepática, com risco associado de insuficiência respiratória e insuficiência cardíaca de alto débito); na presença de complicações locais como hemorragia (raramente é significativa), ulceração (comum, sobretudo no lábio, pescoço e região genital) e necrose; na presença de compromisso das funções sensitivas (no caso de HIs localizados à região peri-ocular com compromisso da abertura palpebral, ou na proximidade do meato auditivo); ou na presença de risco cosmético significativo que poderá levar a deformidades permanentes (localização na asa nasal, lábio superior ou auricular).

O tratamento dos HIs, reservado para as situações anteriormente descritas, era classicamente efetuado utilizando corticoides sistémicos, sendo habitualmente necessário doses altas (superiores a $2 \mathrm{mg} / \mathrm{Kg} / \mathrm{dia}$ ). As taxas de resposta eram variáveis (30 a 80\%) com melhorias duas a três semanas após o início do tratamento, mas os efeitos secundários eram múltiplos (fácies cushingoide, insónia, irritabilidade, alteração do crescimento, hipertensão e cardiomiopatia hipertrófica). A cirurgia reserva-se habitualmente para situações muito pontuais, nomeadamente HIs pediculados.

Recentemente foi descrito um tratamento utilizando o propranolol, um beta-bloqueador não selectivo, que veio revolucionar a abordagem dos HIs. Graças à sua excelente eficácia, comprovada num ensaio randomizado e controlado, rapidamente se tornou no tratamento de primeira linha dos HI. É atualmente o tratamento recomendado pelas principais sociedades científicas estando disponiveis protocolos de orientação. O propranolol deverá ser utilizado durante a fase proliferativa e os seus efeitos terapêuticos são consistentes e rápidos alterando a história natural dos HIs. É um fármaco com boa tolerância clínica embora os efeitos secundários habitualmente associados ao 
propranolol (hipoglicemia, hipotensão, bradicardia

e broncospasmo) devam ser vigiados.

\section{Leitura complementar}

National Institute for Clinical Excellence. Management of atopic eczema in children from birth up to the age of 12 years. London: NICE; 2007.

Eichenfield LF et al. Guidelines of care for the management of atopic dermatitis. J Am Acad Dermatol. 2014.

Léauté-Labrèze C, Dumas de la Roque E, Hubiche T, Boralevi F, Thambo JB, Taïeb A. Propranolol for severe hemangiomas of infancy. N Engl J Med. 2008.

Lawley LP, Siegfried E, Todd JL. Propranolol treatment for hemangioma of infancy: risks and recommendations. Pediatr Dermatol. 2009. 